\title{
Research on Development History of Company town in China
}

\author{
Mingming Xiang ${ }^{1, a^{*}}$, Minghong $\mathrm{Yu}^{2, \mathrm{~b}}$ and Guo $\mathrm{Li}^{3, \mathrm{c}}$ \\ ${ }^{1}$ School of Civil Engineering and Architecture, Southwest University of Science and Technology, \\ Mianyang, China \\ ${ }^{2}$ School of Civil Engineering and Architecture, Southwest University of Science and Technology, \\ Mianyang, China \\ ${ }^{3}$ IBM SLOVAKIA SMART CITY CENTER, Slovak Republic \\ amingmingxiang@hotmail.com, ${ }^{b}$ yuminghong_tb@163.com, ${ }^{c}$ liguo923@hotmail.com
}

\section{Keywords: Company Town; Classified Study; Development History; Industrial Heritage}

Abstract. This paper, from the point of time sequence, classifies Chinese Company Town, and gives a brief overview of Company town's causes, process and characteristics etc. in the colonial times, period of national capitalist industry and the Third Front Construction period, and the present situation of preservation. The paper also advocates that the value of Company town, which should be protected as industrial heritage.

Company towns, as a special spatial form of the industrial sector, have always been closely related to the development of industry. As the locations for living and working of entrepreneurs, workers and their families, it is also inseparable from its own social economic environment.

While the Qing Dynasty ${ }^{1}$ had always taken a policy of Seclusion, which limited science and technology blooming, the history of modern industry in Chinese is relatively short; also its development is also quite different from the countries of Western Europe. Chinese Company town are generally could be divided into three types: the first type is the colonial Company town (1840-1945); the second type is Company town in the period of national capitalist industry (1860 -1949); and after the Communist Party seized power, following a period of stagnation, it began the third type Company town in the period of Third Front Construction (1964-1980).

\section{Company town in the colonial times (1840-1945)}

After the Opium $\mathrm{War}^{2}$ of 1840 , western capitalism began to invade and set up factories in China, this was the beginning of China's modern industry. It forced Chinese natural economy to disintegrate, promoted the development of a commodity economy, and spread the advanced mode of production and production system. The new economic factors in the development of China gave impetus to the national bourgeoisie. It also made China to become the base of a raw materials and commodities market, and the economic dependency on foreign powers forced China into the capitalist world market. It promoted in China primarily uneven industrialization and the native economy with agriculture and family handicraft industry as the main enterprises began to collapse.

From 1843 to 1894, foreign countries had set up a total of 191 industrial enterprises in China, of which 116 belonged to shipbuilding, silk, tea and other export processing industries. Meanwhile Russian and Japanese colonies had achieved great development in northeast China from the early twentieth century to $1945^{3}$. According to statistics, in 1943, the northeast China (where the total land accounted for $12 \%$ and population accounted for $10 \%$ ) produced $93 \%$ of the country's steel, $66 \%$ of its cement, $69 \%$ of its chemical products, and $95 \%$ of its machinery, and founded the world's leading

\footnotetext{
${ }^{1}$ The Qing Dynasty, May 15, 1636 - February 12, 1912, is a dynasty established by Manchu in Chinese history, it was also the last feudal dynasty.

2 The first Opium War or the first Sino-British Trade war, or Trade war, took place in September 4, 1839 (Dao Guang nineteen years (July 27th) to August 29, 1842 (July $24^{\text {th }}$ of Dao Guang twenty-two years). During the war, this is the first large-scale war against China initiated by western countries. The war opened the closed China, which marked the beginning of the modern history of China.

${ }^{3}$ Wang Xun, Yu Qiuhua, Chinese Modern Economic History, Dongbei University of Finance and Economics Press, 2004
} 
technology companies at that time. In 1945, both the scale and the total economic output in northeast had surpassed the amount in Japan, ranking the first in Asia ${ }^{4}$.

At this time, the factories were mostly distributed in southeast coastal China which was colonized by Europe and in the northeast colonized by Japan and Russia. They were led by the European capitalists, the governments of both China and the foreign powers assisted in the construction of plants. The early factories depended very much on city infrastructure facilities which is existed in densely populated areas around the city. They were deeply connected to the development of cities, and complemented each other. Independent Company town were not many, and the boundary of the city was not obvious, such as Shanghai, Dalian, Harbin, etc. After colonial development, service facilities were improved and the city also went to a higher level. But in some remote areas where resource exploitations industry were located, some Company town started from scratch, gradually developed to generate the initial population, and established hospitals, schools, post offices and other service facilities, which finally developed into a town.

One of the typical cases in this period is the HengDaoHezi which has a long history and was influenced by Russian culture. It was developed due to construction of the Middle East Railway. There remain over 250 Russian buildings built during construction of the Middle East Railway in the town, and as a whole, it is the only completely preserved Russian architectural community in China with precious historical value in need of protection and development. There are 97 buildings of Russian style built from 1901 to 1905 with a total construction area of 32,215 square meters ${ }^{5}$. In 2006, it was listed as a national key cultural relic protection unit.

In 1896, the Qing government and tsarist Russia signed the "Sino Russian Mutual Assistance Treaty against the Enemy"6, thus tsarist Russia gained the rights for railways construction in China. The Hengdaohezi is located at the foot of Wanda and Weihu mountains, covering an area of 5.8 square kilometers, in a valley between the two mountains. The special geographical position of the town was one of the difficulties of construction, and a large number of Russian engineers and experts were brought there. At that time, the number of Chinese workers building the route reached 30,000.

In July 1903, the railway was completed. Trains crossing the mountains needed to add an extra locomotive to boost power. Hengdaohezi became the hub of the Dong Qing railway. Since then there has been an important military and political link between China and Russia. Some foreigners came to construct villas and apartments, and opened factories and businesses. Many merchants gathered here, and the title "Garden City" was given to this town. In addition to the activities of commercial and administration, three other pillars to support the town's economy were mainly wood, wine and quarrying. The needs of engineers and residents made the train station, police office, health center, shops of silk and textiles, grocery stores, brothels, churches and other facilities emerge in this barren land. The machine garage, big white towers and Frauenkirche (Russian church) etc. of Russian style buildings had been completed in the town gradually. To provide offices and habitat for Russian experts, technical staff and workers while building railways, more than two hundred Russian buildings were finished. The form and structure of wood houses are compact, beautiful and natural, warm in winter and cool in summer. Also, the carved art is of appreciable value.

In the 90s of last century, internal combustion engine vehicles replaced the steam locomotives. Functions of the train station - water and coal supply, repairing locomotives and others were no longer needed, thus a large number of railway staff moved to Mudanjiang City. Towns built for railways were not thriving like before. The settlement built during the construction of Middle East Railways became bleak. Many historical sites are still there, such as the wooden Orthodox Church, the Middle East Railway machine garage and Russian cemeteries, which are all well preserved. Now it is

\footnotetext{
${ }^{4} \mathrm{Qu}$ Xiaofan, History of Modern Northeast Cities, Northeast Normal University Press, 2001.

5 "A town \& Village Everyday": The 10th episode, the Land Resource Network, Information on http://www.tudinet.com

6 "The Sino Russian Secret Treaty", also known as "Mutual Aid against the Enemy Treaty" or "Defense Treaty of Alliance", was an unequal treaty signed in 1896 by Russian Empire and the Qing government (Guangxu twenty-two years). It has 19 pages, for the redemption of the Liaodong Peninsula, with Russia to boycott Japan which becomes one of the foreign policy of Qing dynasty.
} 
proposed to develop the tourism industry, to achieve industrial restructuring, and repair damaged historic buildings.

\section{Company town in the period of the national capitalist industry $(1860-1949)$}

After the Opium War, the process of deconstructing China's feudal economy and the development of the commodity economy was stimulated and demonstrated by foreign enterprises. Chinese national capitalist industry began to rise in the sixties and seventies of the nineteenth century under the direction of the military industry, and, especially for the civilian industry, under the promoters of the Westernization school ${ }^{7}$.

This stage is named «the development of China's national industry », and there are three reasons. First, the Westernization Movement stimulated the beginning of national industry. After the Sino-Japanese war, the wave of "industrial salvation" gradually promoted the development of the national industry. Second, the Xin Hai Revolution challenged the feudal system. Third, during the First World War, the European powers temporarily relaxed their economic aggression in China. However, after the First World War, in the 30s and 40s of the twentieth century, Japan launched its aggression against China, thus China was involved in the war of eight years, so it's economic and social development was caught in a long-term stagnation.

Early famous Enterprises were mainly the "three factories and one workshop" ${ }^{8}$. Before the SinoJapanese war $^{9}$, there were 260 modern business enterprises, among which most were the light industries, mainly distributed in Shanghai, Tianjin, Guangdong and other coastal areas. Investors in the modern business enterprises were mainly bureaucrats, landlords, merchants (including compradors and handicraft business owners), and they had been transformed into the national bourgeoisie.

For company town of this kind, a typical one is M50 located in the riverside of Suzhou River in Shang Hai. Many kind of the very first national capitalists gathered here. Since opening of Shanghai, grace to its superior geographical position, European and Chinese national capitalists competed for the region and they built factories for production, thus making M50 become one of Chinese largest national capitalists gathering area.

In the battle for precious land, in 1900, Sun Jiading, Number One Scholar in Xianfeng' s governing, Guangxu emperor's teacher, and his younger generations, relatives and friends together raised 30 million liang of silver to establish Fufeng Flour Machine Factory which took the lead in the late period of Qing Dynasty. It became the first flour machine factory in Shanghai started by the national capitalists and gradually became the largest, newest in equipment in the Far East. After a few years, other flour, spinning and textile factories had been built and put into production in the surrounding. The workers residential, shops, hospitals and others as supporting facilities had been gradually improved, forming a bustling and relatively independent workers settlement.

Although in recent years, several buildings in the factory have been designated as the cultural heritage of Shanghai City, yet, it cannot stop some of the old plants from being demolished. At present, the most well-preserved in M50 are the old workshops and its affiliated buildings of Chun Ming Textile Factory which stopped production in the 1990's. In 1999, Chun Ming Textile Factory began to rent the workshops, and accidentally attracted a large number of artists to set up studios, exhibition halls. Until 2005, it was formally authorized as Cultural and Creative Park by the Shanghai government: M50.

\footnotetext{
${ }^{7}$ Westernization School refers to officials endeavored to promote the implementation of "Westernization Movement" (or the Self Strengthening Movement) by the ruling class in the late Qing Dynasty with counterparts as "Conservatives".

${ }^{8}$ Shanghai Fachang machinery factory, Shanghai Hongsheng rice -milling plant,, Jichanglong silk Filature Factory in Nanhai County,Guangdong, Machine mill in Yi Laimou of Tianjin

${ }^{9}$ The First Sino-Japanese War (1 August 1894 - 17 April 1895) was fought between Qing dynasty China and Meiji Japan, primarily over control of Korea. After more than six months of unbroken successes by the Japanese land and naval forces, as well as the loss of the Chinese port of Weihai, the Qing leadership sued for peace in February 1895.
} 


\section{Company town in the Third Front Construction (1964-1980)}

The Third Front Construction started from 1964 when the government of the People's Republic of China began a large scale development of infrastructure including national defense, science and technology, industry, electricity and transportation set on the inter-land in preparation for war and famine. The "Third Front area » is a military geographic concept, including 13 provinces and autonomous regions in the middle and west of China. Its core areas are in the northwest (including now Shaanxi, Gansu, Ningxia and Qinghai) and southwest (including now Sichuan, Chongqing, Yunnan and Guizhou). The starting background was the upgrading of the Vietnam War and the United States' military offensive build up off the southeast coast of China plus the deterioration of the Sino-soviet relationship along with small-scale armed conflicts between the two countries.

From 1964 to 1980, China invested 205.26 billion yuan in the Third Front area, accounting for $39.01 \%$ of total national infrastructure construction. Millions of workers, cadres, intellectuals and servicemen and tens of millions of workers, under the slogans "Preparing for the famine and wars for the people", "Good men and Good Horses Go to Third Front Line", built more than 1100 large and medium-sized industrial and mining enterprises, infrastructure, scientific research units, colleges and universities.

The Third Front Construction changed the industrial economic backwardness in the southwest and northwest of China, making Mianyang, Deyang and Guiyang which were small counties and towns into cities with a large number of modern manufacturing industries and research institutions. However, those factories, infrastructure and enterprises were located mostly in isolated areas, far from their raw materials and related upstream and downstream enterprises. As a matter of urgency, many projects were conducted in a manner of "Design, construction, production are simultaneously executed", which caused a huge waste. After the mid-70s, the national investment in the area was gradually reduced. After the $80 \mathrm{~s}$, a large number of businesses were shut down, while some companies gained a successful transformation, continuing to be the local pillar industry.

\section{Conclusion}

As an industrial heritage, company town is glorious in human history, for it not only bears witnesses to the vicissitudes of history, but also records the ancient civilization. New high-tech industries gradually replace the traditional industries, and the once-great industries have become a heritage forgotten by people gradually - protection of the industrial heritage is a must!

Industrial heritage has double values: material and information. The material value is the use value of industrial heritage as general goods. Information value is as the witness to a special industrial heritage. But many sites have been forgotten and destroyed, and the current status of industrial heritage is very worrying. Transformation and protection solutions are needed urgently.

\section{References}

[1] Xun Wang, Qiuhua Yu, Chinese Modern Economic History, Dongbei University of Finance and Economics Press, 2004. (In Chinese)

[2] Xiaofan Qu, History of Modern Northeast Cities, Northeast Normal University Press, 2001.（In Chinese)

[3] "A town \& Village Everyday": The 10th episode, the Land Resource Network, Information on http://www.tudinet.com. (In Chinese)

[4] Chuncai Wang, China Flame, Sichuan People's Publishing House, 1993. (In Chinese ) 